11/167). Die 5-Jahres-Überlebensrate (alterskorrigiert nur RO) hat sich verbessert (1969-1975 $46 \pm 11 \%$; $1976-198075,8 \pm 10 \%$. Die Lokalrezidivrate fiel in den beobachteten Zeiträumen von $29,8 \%$ auf $18,2 \%$. Die Stadienverteilung der Carcinome ist gleich geblieben. Bei Carcinomen des mittleren Rectumdrittels kann daher ohne Erhöhung des Risikos eine anteriore Rectumresektion durchgeführt werden.

Schliisselwörter: Rectumcarcinom - Resektion - Extirpation - Überlebensraten.

\title{
216. Die transanale Resektion des tiefsitzenden Rectumcarcinoms
}

\author{
Ch. Scheele und K. Reichel \\ Chirurgische Klinik im Städt. Krankenhaus Siloah Hannover, Roesebeckstraße 15, D-3000 Hannover 91
}

\section{The Transanal Excision of Low Rectal Cancer}

Summary. Abdomino-perineal excision is the preferred method for the curative treatment of low rectal cancer. In clearly defined cases the alternative of a local transanal excision should be considered as an operation preserving continence. A local transanal tumor excision was performed in 25 patients as curative treatment. The postoperative period of observation encompasses 10 years. Results have shown that it is possible to heal a small carcinoma of the rectum by transanal excision if discovered at an early stage.

Key words: Low rectal cancer - Local transanal excision - Curative treatment.

Zusammenfassung. In der kurativen Behandlung des tiefsitzenden Rectumcarcinoms gilt die abdominoperineale Amputation als Operationsmethode der Wahl. Alternativ bietet sich in ausgewählten Fällen bei strenger Indikationsstellung die lokale, transanale Resektion als kontinenzerhaltender Eingriff an. Bei 25 Patienten wurde einen lokale, transanale Tumorresektion als Kurativeingriff durchgeführt. Der postoperative Beobachtungszeitraum umfaßt 10 Jahre. Die Resultate zeigen, daß man das frühzeitig entdeckte, kleine Rectumcarcinom durch transanale Resektion heilen kann.

Schlüsselwörter: Tiefsitzendes Rectumcarcinom - Lokale, transanale Resektion - Kurativeingriff.

\section{Ist die örtliche Excision des kleinen Rectumcarcinoms gefährlich oder ausreichend?}

\author{
D. Staimmer und A. Wilhelm
}

Allgemeinchirurgische Abteilung, Krankenhaus München-Neuperlach, Oskar-Maria-Graf-Ring 51, D-8000 München 83

\section{Is Local Excision for Early Cancer of the Rectum Dangerous or Adequate?}

Summary. Local excision of the rectum in cases of small carcinomas is a successful and accepted method. It is a satisfactory operation for well and moderately differentiated carcinomas spread into the submucosa. However local excision is dangerous for poorly differentiated cancer because lymphnode metastases occur in $50 \%$ of cases. If the tumor has spread into the muscularis propria plane or over it, local excision should be performed only by way of exception. If lymph or blood vessels are infiltrated, excision of the rectum should be performed. Key words: Rectum carcinoma - Local excision.

Zusammenfassung. Die örtliche Excision des kleinen Rektumcarcinomas ist eine anerkannte und erfolgreiche Operationsmethode. Sie ist ausreichend beim gut und mäßig differenzierten Carcinom mit Infiltration in die Submucosa. Gefährlich ist sie beim schlecht differenzierten Carcinom, da in $50 \%$ der Fälle Lymphknotenmetastasen auftreten. Die örtliche Excision sollte bei Carcinom-Infiltration in oder über die Muscularis propria hinaus nur in großen Ausnahmefällen durchgeführt werden. Auch beim Einbruch des Carcinoms ins Gefäßsystem ist die Radikaloperation vorzuziehen.

Schlïsselwörter: Rectumcarcinom - Örtliche Excision. 